\title{
Recent Advances in Colonic Preparation for an Accurate Colonoscopy - How to Improve Our Practice to Meet the Quality Criteria
}

\author{
Mihai-Radu PAHOMEANU' ${ }^{1}$, Lucian NEGREANU ${ }^{\top}$
}

\begin{abstract}
Colorectal cancer (CRC) remains a major problem of global health. Screening colonoscopy is the gold standard in detection of CRC. A quality colonoscopy needs good indication, adequate bowel preparation, adequate examination time (30 to 45 minutes), a minimum 6 minutes time for mucosal examination during colonoscopy descent, a good centre adenoma detection rate. In 28-33\% of the colonoscopies, the bowel preparation is unsatisfactory which leads to several hidden costs including the rise of preventable and treatable death rate regarding colorectal carcinoma. The ESGE (European Society of Gastrointestinal Endoscopy) recommends a maximum of 10\% poor preparations, threshold that is difficult to reach in many centres. Newer low-volume laxative regimens for bowel cleansing are better in the fields of compliance and tolerability than the classic 4L PEG with 2L PEG-CS (Clensia ${ }^{\circledR}$ ) being one of the new promising low-volume formulas. The low fibre diet is now preferred due to better compliance and tolerability. Conclusions: One of the easiest ways to improve colonoscopy quality is through improved compliance. Two of the most effective measures are using newer laxative bowel cleansing formulas (like 2L PEG-CS) and a low-fibre diet.
\end{abstract}

Keywords: bowel preparation, 2L PEG-CS, low-volume laxatives, simethicone, low fibre diet.

\section{Rezumat}

Cancerul colorectal (CCR) rămâne o problemă majoră de sănătate publică. Calitatea colonoscopiilor trebuie să fie îmbunătățită pentru a preveni CCR și pentru aceasta ESGE recomandă o pregătire intestinală adecvată, timpul dedicat colonoscopiei să fie între 30-45 de minute, timpul minim de observare a mucoasei la coborâre de minimum 6 minute, o rată satisfăcătoare de detecție a adenoamelor sau a polipilor la nivelul centrului, necesitatea intubației cecale, necesitatea indicației, etc. În circa 28-33\% dintre colonoscopii, pregătirea intestinală este nesatisfăcătoare, aceasta ducând la costuri ascunse precum rata de decese prevenibile sau tratabile a cancerului colo-rectal. ESGE recomandă un maximum de 10\% pregătiri neadecvate, limită ce este dificil de atins. Noi formule laxative de volum mic pentru curățarea intestinului sunt mai bune în ceea ce privește complianța și tolerabilitatea în comparație cu regimul clasic 4L PEG. 2L PEG-CS (Clensia ${ }^{\circledR}$ ) este formula cu datele cele mai promițătoare, dintre cele de volum mic. Dieta săracă în fibre a ajuns să fie și ea preferată din motive similare. Concluzii: Cea mai facilă cale de a îmbunătăți calitatea colonoscopiilor este creșterea complianței. Două metode ușoare de a realiza aceasta sunt folosirea noilor formule laxative pentru curățarea intestinului (precum 2L PEG-CS) și dieta săracă în fibre.

Cuvinte cheie: pregătire intestinală, 2L PEG-CS, laxative de volum mic, simeticonă, dietă.

\footnotetext{
${ }^{1} 2^{\text {nd }}$ Department of Gastroenterology, Emergency University Hospital, „Carol Davila" University of Medicine and Pharmacy, Bucharest, Romania
}

Corresponding author.

Lucian NEGREANU, Emergency University Hospital, Bucharest, Romania.

E-mail: negreanu_99@yahoo.com 


\section{INTRODUCTION}

Large bowel preparation is a highly important step in the process of a successful colonoscopy. Nowadays, ESGE (European Society of Gastrointestinal Endoscopy, Germany, EU) and UEG (United European Gastroenterology, Austria, EU) are recommending a rate of adequate bowel preparation of at least $90 \%$ calculated on a daily basis for the entire endoscopy centre and also for every practitioner in part ${ }^{1}$.

Due to the poor tolerability, acceptability and compliance of the standard 4L PEG regimens ${ }^{2}$, newer low volume PEGs were formulated and brought to the market with solid evidence in terms of efficacy and also of tolerability. Recently a formulation of 2L PEG + citrate and simethicone (PEG-CS) became commercially available (Clensia ${ }^{\circledR}$, Alfasigma SpA, Italy, EU). Its main advantage is that it adds to the regular low volume regime 2L PEG and citrate, the de-foaming agent simethicone that is effective in cleaning the bubbles formed on the bowel mucosa which can hinder the detection of small lesions ${ }^{3,4}$. Simethicone, as an anti-foaming agent, was employed for decades but after concerns regarding the biofilm that simethicone makes when flushed though endoscopic channels and which might raise the potential of an infection risk, this practice was no longer recommened ${ }^{5}$. The main benefit of PEG-CS is that simethicone is administered per os with the low volume preparation itself.

The low fibre diet is also gaining momentum versus the classical clear liquid diet. This is so because it had been observed in several meta-analyses that the same efficacy can be gained but with better tolerability and compliance than the standard clear liquid diet ${ }^{2}$.

\section{Quality colonoscopy-role of a good preparation}

In order to perform an adequate colonoscopy, ESGE and UEG, had published a number of quality criteria 1: clear indication for the examination, adequate bowel preparation, sufficient time recommended to perform the exam (30 to 45 minutes, at least 6-10 minutes for withdrawal time), good adenoma detection rate (ADR) or polyp detection rate (PDR) for the centre and each practitioner, adequate control of cecal intubation rates, appropriate technique of polypectomy etc.

There are a lot of scales that were put in place to standardize the quality of colonic preparation, the most important ones being the Boston Bowel Preparation Scale (BBPS), Ottawa Scale and Aronchick Scale ${ }^{6}$. A new scale that assesses the bubbles that are forming on the bowel mucosa surface and how they can impair detection of lesions, named Colon Endoscopic Bubble Scale $(\mathrm{CEBuS})$, is now under validation with promising results ${ }^{3}$.

Several studies ${ }^{7,8}$, have shown that the missed lesions at preceding colonoscopies, were most of the times a result of low-quality examinations. The missed lesions are developing mostly in right colon but also in the rectum, regions hard to carefully examine without a good cleanliness of the mucosa. In the near future, we should expect that the AI software will improve detection of lesions, coming handy for most of the colonoscopists but with the same condition of an adequate preparation.

The poor tolerance at the administration of oral bowel cleansing laxatives can create a low compliance leading to poor colonic cleaning and consequently a risk for lower ADR and interval cancer hence a necessity to repeat the examination in the following three months. In order to avoid patient discomfort and excess costs and risks, a lot of importance was given to patient education regarding the need of a good preparation (smart phone apps, instruction forms with photos, surveillance of certain at-risk patients by a dedicated nurse etc) but also for developing lower volume preparations that will increase acceptance and compliance.

The two main classes of bowel cleansing osmotic laxatives are the ones based on polyethylene-glycol (PEG) and the ones based on sodium phosphate. More than half of the patients can have side effects, most frequently nausea, bloating and abdominal pain, all of which associated with dehydration and electrolyte loss. Several cases of acute renal injury were published with the sodium phosphate regimens use, which lead to formal avoidance of these preparations nowadays ${ }^{6}$.

The patient should be also aware of the importance of the oral hydric input, because this can prevent most of the unwanted effects and it would improve the adequate colonic preparation and the quality of the colonoscopy ${ }^{9}$.

Once the American Cancer Society (Georgia, USA) proposed the modification of the threshold age for $\mathrm{co}^{-}$ lorectal cancer screening start from 50 to $45^{10}$, a significant number of patients being diagnosed with early stage CRC or even high-risk precancerous lesions at an earlier age. Most of those are small lesions, flat lesions difficult to spot even by an experimented endoscopist, if the preparation is not optimal ${ }^{11}$. 


\section{Colonic preparation regimens}

A retrospective study on 133 patients, showed a miss rate of almost $50 \%$ for the detection of adenomas or high-risk dysplasia, in patients with an inadequate initial bowel preparation ${ }^{12}$. The latest recommendation on behalf of the expert's panel of $\mathrm{ESGE}^{2}$ suggest a minimum $90 \%$ rate of adequate bowel preparation for every centre and endoscopist as a quality criterion.

In a 2012 prospective study of 2811 patients, 33\% had an inadequate level of bowel preparation ${ }^{13}$, associated with cirrhosis, Parkinson disease, diabetes mellitus and previous colorectal surgery.

A recent retrospective study of inflammatory bowel disease (IBD) patients which due to their pathology and due to the necessity to undergo many colonoscopies for CCR surveillance already have a poor adherence to their screening regimen, concurred that $28 \%$ of the colonoscopies are also poorly prepared (BBPS $<6)^{14}$. Hence, indication of preparation regimen should be personalized and extensive explanations about the importance of a clean mucosa should be given for each patient.

In Romania the annual rate of preventable or treatable deaths associated with CRC (ICD: C18-C21) was estimated in 2017 at 20.4/100000 inhabitants ${ }^{15}$, so we find mandatory to improve patients' access to screening and also to increase adherence and compliance by using the right colonic preparation regimens.

Today, the main guidelines ${ }^{2,16}$ are accepting lower volume laxative regimens. We recognise that as long as the cleansing is similar, the smaller the volume, the greater is the tolerability and acceptance of the patient. However, in regard with the very-low volume regimes $(<1 \mathrm{~L})$, there are still conflicting studies as recently as $2020^{17,18}$. None of the studies detected any significant improvement in bowel cleansing, the main improvement being a better tolerability in one of the studies.

There are several meta-analyses published on the topic low volumes of 2L PEG-based regimens, we will concentrate only on the most recently published ones.

Spadaccini et al. ${ }^{19}$ analysed $17 \mathrm{RCTs}$, comprising 7528 patients that were administered low-volume split-dose regimens and found no difference in the efficacy, stating they managed to see an improvement in tolerability and compliance compared with the regular 4L PEG regimens. A Chinese meta-analysis ${ }^{20}$ showed similar results as Spadaccini et al., only to add that low volume regimens are enjoying also a higher acceptability and a lower nausea in non-selected population.
Several RCT's published recently are analysing efficacy, safety and tolerability of 2L PEG-based bowel cleansing laxatives. A French randomized multi-centric, prospective study ${ }^{21}$, that enrolled 278 patients, has managed to conclude that low volume 2L PEG and Pico based regimens were more efficient, better tolerated and equally safe as the 4L PEG-based regimens. Even if the aforementioned study is focusing only on IBD patients, other randomized prospective studies, with a larger focus group had managed to achieve similar outcomes. A 2019 Chilean study ${ }^{22}$ that standardised bowel cleansing with BBPS found in the $2 \mathrm{~L}$ PEG group a 5\% improvement of the colonic cleansing, although it was not statistical relevant, and no differences in regard with the safety and tolerability of newer regimens.

In choosing the best type of low-volume bowel preparation we should be also aware of the pre-endoscopic factors that could impair quality of preparation. Brown liquid rectal effluent, cirrhosis, low 3-days diet compliance and more than 2 hours between last defecation and colonoscopy are independent predictors for poor colonic preparation in the moment of the examination as shown by a 2019 Korean prospective study ${ }^{23}$ using 2L PEG-ASC formula.

The 2L PEG-CS (polyethylene-glycol + citrate and simethicone) is a relatively new but promising bowel cleansing laxative formula. This formula represents an improvement of the regular 2L PEG-C with the addition of simethicone, an anti-foaming agent that is capable of reducing the bubble formation on the colonic mucosa ${ }^{3}$. Even if simethicone was used through endoscopic channels for intra-procedural bubble cleansing, it frequently developed a biofilm that was difficult to remove.

The fact that simethicone is now added to the laxative regimen represents nothing a breakthrough. The PEG-CS regimen has been the subject of a lot of validation studies with at least similar efficacity in terms of bowel cleansing as 4L regimens or PEG ASC. Spada et al. ${ }^{24}$ proved via an observer-blind RCT on 422 patients that compared it with the $4 \mathrm{~L}$ PEG regimen, that 2L PEG-CS had an improvement of $1.3 \%$ in bowel cleansing with no side effects observed. Gastrointestinal tolerability, acceptability on behalf of patients and willingness-to-repeat were far greater with the new formula.

In 2018, a group of European experts, compared in a multicentre observer-blind $\mathrm{RCT}^{25}$ the $2 \mathrm{~L}$ PEG-CS formula this time with another low-volume regimen, 
namely the 2L PEG-ASC. They concluded that there are no differences in terms of bowel cleansing, safety and acceptance between the two formulas.

Some trials are preferring to see if combining the 2L PEG-CS regimen with administration of bisacodyl within several days before the colonoscopy will improve the preparation. Bisacodyl is an orally available laxative, indicated in constipation, that works by irritating the smooth muscle of the bowel that in turn will increase peristalsis and also increases intestinal fluid accumulation ${ }^{26}$. There is an $\mathrm{RCT}^{27}$ that demonstrated the superiority in efficacy of PEG-CS with bisacodyl versus PEG-ASC, and another one ${ }^{28}$ that showed similar efficacy with 4L PEG, but with better tolerability and acceptance.

The ESGE guideline ${ }^{2}$ presents the main options in the field of low volume laxative bowel cleansing regimens (Table 1). Even if newer formulas as 2L PEGCS $\left(\right.$ Clensia $\left.^{\circledR}\right)$ are not part of the latest recommendation, they are similar with $2 \mathrm{~L} \mathrm{PEG} \mathrm{+} \mathrm{citrate} \mathrm{and} \mathrm{the}$ guideline states very clearly that any clinically validated routine bowel preparation should be administered if the practitioner finds it effective. Also, there is a formal recommendation for adding oral simethicone to bowel preparation, a low fibre diet on the day preceding the exam, the use of enhanced instructions, splitting of the dose of bowel cleansing laxative, starting the last dose within 5 hours before examination and completing it at least 2 hours before colonoscopy and same-day preparation for afternoon colonoscopies.

\section{Low-fibre diet}

Despite the classical dogma accepted until very recently that the day preceding colonoscopy, the patient should have a clear liquids diet, there are more and more evidences that there is no difference in efficacity between clear liquid diet and low-residue diet.

Table 1. Low volume PEG based bowel cleansing laxative formulas given as example by ESGE 2

\begin{tabular}{|l|l|}
\hline $\begin{array}{l}\text { Type of low volume } \\
\text { regimen }\end{array}$ & Not recommended in: \\
\hline 2L PEG + citrate & $\begin{array}{l}\text { Severe renal insufficiency, congestive heart } \\
\text { failure, unstable angina or acute myocardial } \\
\text { infarction }\end{array}$ \\
\hline 2L PEG + ascorbate & $\begin{array}{l}\text { Severe renal insufficiency, congestive heart } \\
\text { failure, phenylketonuria, G-6-PD deficiency }\end{array}$ \\
\hline 2L PEG + bisacodyl & $\begin{array}{l}\text { Congestive cardiac failure. } \\
\text { Occasional reports of ischemic colitis. }\end{array}$ \\
\hline 1L PEG + ascorbate & $\begin{array}{l}\text { Severe renal insufficiency, congestive heart } \\
\text { failure, phenylketonuria, G-6-PD deficiency }\end{array}$ \\
\hline
\end{tabular}

The latest ESGE guideline ${ }^{2}$ is recommending a low fibre diet in the day before the colonoscopy. A low fibre diet is made up by aliments like cheese, meat, fish, white bread, some fresh peeled and pitted fruits or cooked vegetables (like apples or carrots). Even if there is no difference in efficacity, the compliance and tolerability was far better than in those with clear liquid diet.

We identified two $\mathrm{RCT}^{29,30}$ that concluded the low fibre diet is superior in terms of tolerability in regard with the clear diet protocol. While Alvarez-Gonzalez et al. found a better efficacy in 1-day normocaloric lowfibre diet, Thukral et al. found none, but emphases that the low-fibre diet should be recommended in regards with better satisfaction scores.

In regard with the necessary time for the special diet, two $\mathrm{RCT}^{31,32}$ found no improvement in the 3-day diet versus 1-day diet, both with the low-fibre regime. Taveira et al. also found statistically significant difficulties for the patients in performing the diet for 3 straight days.

We should acknowledge the existence and acceptance by the ESGE of a pre-packaged low-residue diet. In a 2019, an endoscopist-blinded $\mathrm{RCT}^{33}$ that included 173 patients showed a statistically significant improvement in bowel preparation, as measured with BBPS of $5,7 \%$ in the group that used pre-packaged low-residue diet. Also, a significant satisfaction and willingness to repeat the procedure was obtained in this group.

\section{CONCLUSION}

In order to improve colonoscopy quality and reach the 90\% adequate bowel preparation milestone imposed by current recommendations a lot of measures should be taken. Patient education, low volume preparations including the new $2 \mathrm{~L}$ polyethylene-glycol citrate simethicone (PEG-CS) and a low residue diet in the day preceding the examination seem to be effective and easy to employ measures that will increase the quality of colonoscopy for the benefit of our patients.

Compliance with ethics requirements: The authors declare no conflict of interest regarding this article. The authors declare that all the procedures and experiments of this study respect the ethical standards in the Helsinki Declaration of 1975, as revised in 2008(5), as well as the national law. Informed consent was obtained from all the patients included in the study. 


\section{References}

1. Kaminski MF, Thomas-Gibson $S$, Bugajski $M$, Bretthauer $M$, Rees CJ, Dekker E, et al. Performance measures for lower gastrointestinal endoscopy: a European Society of Gastrointestinal Endoscopy (ESGE) Quality Improvement Initiative. Endoscopy [Internet]. 2017 Apr 1 [cited 2020 Aug 28];49(4):378-97. Available from: https://pubmed.ncbi.nlm.nih.gov/28268235

2. Hassan C, East J, Radaelli F, Spada C, Benamouzig R, Bisschops $R$, et al. Bowel preparation for colonoscopy: European society of gastrointestinal endoscopy (ESGE) guideline-update 2019. Endoscopy. 2019;51(8):775-94.

3. Taveira, Filipe, Hassan, C, Kamniski M, F, Negreanu L. The colon endoscopic bubble scale (CEBUS): a reliability study. UEG Week. 2020.

4. Zhang S, Zheng D, Wang J, Wu J, Lei P, Luo Q, et al. Simethicone improves bowel cleansing with low-volume polyethylene glycol: A multicenter randomized trial. Endoscopy [Internet]. $2018 \mathrm{Apr}$ 1 [cited 2020 Aug 29];50(4):412-22. Available from: https://pubmed.ncbi.nlm.nih.gov/29132175.

5. Devereaux BM, Taylor ACF, Athan E, Wallis DJ, Brown RR, Greig SM, et al. Simethicone use during gastrointestinal endoscopy: Position statement of the Gastroenterological Society of Australia [Internet]. Vol. 34, Journal of Gastroenterology and Hepatology (Australia). Blackwell Publishing; 2019 [cited 2020 Aug 29]. p. 2086-9. Available from: https://pubmed.ncbi.nlm.nih. gov/31242327.

6. Boieriu E, Negreanu L. Screening for colorectal cancer: what's new in 2019? Medic.ro. 2019;1(127):47.

7. Castaneda D, Popov VB, Verheyen E, Wander P, Gross SA. New technologies improve adenoma detection rate, adenoma miss rate, and polyp detection rate: a systematic review and metaanalysis [Internet]. Vol. 88, Gastrointestinal Endoscopy. Mosby Inc.; 2018 [cited 2020 Sep 2]. p. 209-222.e11. Available from: https://pubmed.ncbi.nlm.nih.gov/29614263.

8. Pohl H, Robertson DJ. Colorectal cancers detected after colonoscopy frequently result from missed lesions. Clinical Gastroenterology and Hepatology [Internet]. 2010 Oct [cited 2020 Sep 2];8(10):858-64. Available from: https://pubmed.ncbi.nlm.nih. gov/20655393/

9. Dykes C, Cash BD. Key safety issues of bowel preparations for colonoscopy and importance of adequate hydration [Internet]. Vol. 31, Gastroenterology Nursing. Gastroenterol Nurs; 2008 [cited 2020 Sep 2]. p. 30-5. Available from: https://pubmed.ncbi. nlm.nih.gov/18300822.

10. Wolf AMD, Fontham ETH, Church TR, Flowers CR, Guerra CE, LaMonte SJ, et al. Colorectal cancer screening for average-risk adults: 2018 guideline update from the American Cancer Society. CA: A Cancer Journal for Clinicians [Internet]. 2018 Jul 1 [cited 2020 Aug 29];68(4):250-81. Available from: https://acsjournals.onlinelibrary.wiley.com/doi/full/10.3322/caac.21457.

11. Froehlich F, Wietlisbach V, Gonvers JJ, Burnand B, Vader JP. Impact of colonic cleansing on quality and diagnostic yield of colonoscopy: The European Panel of Appropriateness of Gastrointestinal Endoscopy European multicenter study. Gastrointestinal Endoscopy. 2005 Mar 1;61(3):378-84.

12. Chokshi R v., Hovis CE, Hollander T, Early DS, Wang JS. Prevalence of missed adenomas in patients with inadequate bowel preparation on screening colonoscopy. Gastrointestinal Endoscopy. 2012 Jun 1;75(6):1197-203.

13. Hassan C, Fuccio L, Bruno M, Pagano N, Spada C, Carrara S, et al. A Predictive Model Identifies Patients Most Likely to Have Inadequate Bowel Preparation for Colonoscopy. Clinical Gastroenterology and Hepatology [Internet]. 2012 May [cited 2020 Aug 29];10(5):501-6. Available from: https://pubmed.ncbi.nlm. nih.gov/22239959.
14. Negreanu L, Voiosu T, State M, Mateescu RB. Quality of colonoscopy preparation in patients with inflammatory bowel disease: retrospective analysis of 348 colonoscopies. Journal of International Medical Research. 2020;48(4).

15. Eurostat - Data Explorer [Internet]. [cited 2020 Aug 29]. Available from: https://appsso.eurostat.ec.europa.eu/nui/submitViewTableAction.do.

16. Johnson DA, Barkun AN, Cohen LB, Dominitz JA, Kaltenbach T, Martel $\mathrm{M}$, et al. Optimizing adequacy of bowel cleansing for coIonoscopy: recommendations from the U.S. Multi-Society Task Force on Colorectal Cancer EFFECT OF INADEQUATE PREPARATION ON POLYP/ADENOMA DETECTION AND RECOMMENDED FOLLOW-UP INTERVALS Recommendations. Gastrointestinal Endoscopy [Internet]. 2014 [cited 2020 Sep 2];80:543-62. Available from: http://dx.doi.org/10.1016/j.gie.2014.08.002.

17. Pisera M, Franczyk R, Wieszczy P, Polkowski M, Rupinski M, Chaber-Ciopinska A, et al. The impact of low- versus standardvolume bowel preparation on participation in primary screening colonoscopy: A randomized health services study. Endoscopy [Internet]. 2019 [cited 2020 Sep 2];51(3):227-36. Available from: https://pubmed.ncbi.nlm.nih.gov/30634195.

18. Hernandez P V., Horsley-Silva JL, Snyder DL, Baffy N, Atia M, Koepke $L$, et al. Effect of bowel preparation volume in inpatient colonoscopy. Results of a prospective, randomized, comparative pilot study. BMC Gastroenterology [Internet]. $2020 \mathrm{Jul} 13$ [cited 2020 Sep 2];20(1):227. Available from: https://bmcgastroenterol.biomedcentral.com/articles/10.1186/s12876-020-01373-1

19. Spadaccini M, Frazzoni L, Vanella G, East J, Radaelli F, Spada C, et al. Efficacy and Tolerability of High- vs Low-Volume Split-Dose Bowel Cleansing Regimens for Colonoscopy: A Systematic Review and Meta-analysis [Internet]. Vol. 18, Clinical Gastroenterology and Hepatology. W.B. Saunders; 2020 [cited 2020 Sep 2]. p. 1454-1465.e14. Available from: https://pubmed.ncbi.nlm. nih.gov/31683057

20. Yi L-J, Tian X, Shi B, Chen H, Liu X-L, Pi Y-P, et al. Low-Volume Polyethylene Glycol Improved Patient Attendance in Bowel Preparation Before Colonoscopy: A Meta-Analysis With Trial Sequential Analysis. Frontiers in Medicine [Internet]. 2019 May 6 [cited 2020 Sep 2];6. Available from: https://pubmed.ncbi.nlm. nih.gov/31134201

21. Briot C, Faure P, Parmentier AL, Nachury M, Trang C, Viennot S, et al. Efficacy, Tolerability, and Safety of Low-Volume Bowel Preparations for Patients with Inflammatory Bowel Diseases: The French Multicentre CLEAN Study. Journal of Crohn's and Colitis [Internet]. 2019 Sep 1 [cited 2020 Sep 2];13(9):1121-30. Available from: https://pubmed.ncbi.nlm.nih.gov/30785181/

22. López S, Vargas C, López C. Effectiveness and tolerability of low volume bowel cleansing polyethylene glycol solution for colonoscopy. Revista Medica de Chile [Internet]. 2019 [cited 2020 Sep 2];147(8):977-82. Available from: https://pubmed.ncbi. nlm.nih.gov/31859961.

23. Shin SY, Ga KS, Kim IY, Park YM, Jung DH, Kim JH, et al. Predictive factors for inadequate bowel preparation using low-volume polyethylene glycol (PEG) plus ascorbic acid for an outpatient colonoscopy. Scientific Reports [Internet]. 2019 Dec 1 [cited 2020 Sep 2];9(1). Available from: https://pubmed.ncbi.nlm.nih. gov/31873135.

24. Spada C, Cesaro P, Bazzoli F, Saracco GM, Cipolletta L, Buri L, et al. Evaluation of Clensia ${ }^{\circledR}$, a new low-volume PEG bowel preparation in colonoscopy: Multicentre randomized controlled trial versus 4L PEG. Digestive and Liver Disease [Internet]. 2017 Jun 1 [cited 2020 Sep 2];49(6):651-6. Available from: https://pubmed.ncbi.nlm.nih.gov/28233684.

25. Kump P, Hassan C, Spada C, Brownstone E, Datz C, Haefner M, et al. Efficacy and safety of a new low-volume PEG with citra- 
te and simethicone bowel preparation for colonoscopy (Clensia): a multicenter randomized observer-blind clinical trial vs. a low-volume PEG with ascorbic acid (PEG-ASC). Endoscopy International Open [Internet]. 2018 Aug 1 [cited 2020 Sep 2];06(08):E907-13. Available from: http://www.thieme-connect.de/DOI/DOI?10.1055/a-0624-2266.

26. Dulcolax, Correctol (bisacodyl) dosing, indications, interactions, adverse effects, and more [Internet]. [cited 2020 Sep 3]. Available from: https://reference.medscape.com/drug/dulcolax-correctol-bisacodyl-342008\#10.

27. Repici A, Cestari R, Annese V, Biscaglia G, Vitetta E, Minelli L, et al. Randomised clinical trial: Low-volume bowel preparation for colonoscopy - A comparison between two different PEG-based formulations. Alimentary Pharmacology and Therapeutics [Internet]. 2012 Oct [cited 2020 Sep 3];36(8):717-24. Available from: https://pubmed.ncbi.nlm.nih.gov/22924336.

28. Valiante F, Bellumat $\mathrm{A}$, de Bona M, de Boni M. Bisacodyl plus split 2-L polyethylene glycol-citrate-simethicone improves quality of bowel preparation before screening colonoscopy. World Journal of Gastroenterology [Internet]. 2013 [cited 2020 Sep 3];19(33):5493-9. Available from: https://pubmed.ncbi. nlm.nih.gov/24023492.

29. Alvarez-Gonzalez MA, Pantaleon MA, Flores-Le Roux JA, Zaffalon D, Amorós J, Bessa X, et al. Randomized clinical trial: A normocaloric low-fiber diet the day before colonoscopy is the most effective approach to bowel preparation in colorectal cancer screening colonoscopy. Diseases of the Colon and Rectum
[Internet]. 2019 Apr 1 [cited 2020 Sep 3];62(4):491-7. Available from: https://pubmed.ncbi.nlm.nih.gov/30844973.

30. Thukral C, Tewani SK, Lake AJ, Shiels AJ, Geissler K, Popejoy $S$, et al. Results of a Community-based, Randomized Study Comparing a Clear Liquid Diet with a Low-residue Diet Using a Magnesium Citrate Preparation for Screening and Surveillance Colonoscopies. Journal of Clinical Gastroenterology [Internet]. 2019 Jan 1 [cited 2020 Sep 3];53(1):34-9. Available from https://pubmed.ncbi.nlm.nih.gov/29112048.

31. Gimeno-García AZ, de La Barreda Heuser R, Reygosa C, Hernandez A, Mascareño I, Nicolás-Pérez D, et al. Impact of a 1-day versus 3-day low-residue diet on bowel cleansing quality before colonoscopy: A randomized controlled trial. Endoscopy [Internet]. 2019 [cited 2020 Sep 3];51(7):628-36. Available from: https://pubmed.ncbi.nlm.nih.gov/30943553.

32. Taveira F, Areia M, Elvas L, Alves S, Brito D, Saraiva S, et al. A 3-day low-fibre diet does not improve colonoscopy preparation results compared to a 1-day diet: A randomized, single-blind, controlled trial. United European Gastroenterology Journal [Internet]. 2019 Dec 1 [cited 2020 Sep 3];7(10):1321-9. Available from: https://pubmed.ncbi.nlm.nih.gov/31839957.

33. Lee JW, Choi JY, Yoon H, Shin CM, Park YS, Kim N, et al. Favorable outcomes of prepackaged low-residue diet on bowel preparation for colonoscopy: Endoscopist-blinded randomized controlled trial. Journal of Gastroenterology and Hepatology (Australia) [Internet]. 2019 May 1 [cited 2020 Sep 3];34(5):8649. Available from: https://pubmed.ncbi.nlm.nih.gov/30278110. 